\title{
Az Amerikai Egyesült Államok és a párizsi egyezmény
}

The United States of America and the Paris Agreement

Schneider Richárd

https://doi.org/10.47707/Kulugyi Szemle.2021.1.04

Összefoglaló: Az 1992-es riói egyezmények után a 2015-ben elfogadott párizsi egyezmény az univerzális jellegének és az Egyesült Államok részvételének köszönhetően szintén mérföldkőnek számított a nemzetközi éghajlatvédelem terén. A 2009 és 2017 közötti demokrata kormányzás alatt a klímaváltozás elleni fellé pés számos tekintetben meghatározó eleme volt az amerikai bel- és külpolitikai napirendnek. Az Obama-adminisztrációnak a párizsi egyezménnyel kapcsolatos sikerei remekül szemléltetik az e területen megvalósult hatékony amerikai érdek érvényesitést. A 2019. november 4-én bejelentett amerikai kilépés következtében azonban az egyezményben kitűzött célok teljesítése bizonytalanná vált. s így a multilaterális keretek között tett erőfeszitések hatékonyságát is alapjaiban kérdőjelezte meg. A kilépésröl szóló döntés mindeközben egy konzekvens republiká nus klímapolitika következménye volt, amely beleillett a Trump-adminisztráció által képviselt izolacionista külpolitikai vonalvezetésbe. A demokrata elnökjelölt. Joe Biden választási győzelmével, valamint az egyezményhez való újracsatlakozással azonban egy új(abb) fejezet nyílik mind az amerikai, mind a nemzetközi éghajlatvédelem történetében. A jelen elemzés az elmúlt évek amerikai klímapolitikájának a megértését hivatott elősegíteni az említett folyamatok részletes vizsgálatán keresztül, különösen a párizsi egyezmény kontextusában.

Kulcsszavak: párizsi egyezmény, Egyesült Államok, éghajlatváltozás, klímapolitika

Abstract: Second to the 1992 Rio Conventions, the Paris Agreement is certainly a milestone in the field of international climate protection due to its universal nature and the full commitment and participation of the United States therein. During the Democrats term between 2009 and 2017. climate protection became a determining element of the American foreign and internal affairs in many respects. The implementation of the Paris Agreement by the Obama administration is a good example for effective enforcement of commitments. However, when the United States' 


\section{Külïgyi Szemle}

withdrawal from the Agreement was officially announced in 2019. the fulfilment of climate targets became uncertain. which in turn questioned the actual efficiency of any multilateral climate protection endeavour. At the same time. the American exil was a consequence of a consistent Republican climate policy, which actually fit into the Trump administration's isolationist approach. Joe Biden's victory in the presidential elections and the decision to rejoin the Agreement mean that a new chapter started in both American and in international climate protection. The purpose of this analysis is to promote a better understanding of the American climate policy during the last few years through the examination of the aforementioned processes, specifically in the context of the Paris Agreement.

Keywords: Paris Agreement, United States, climate change, climate policy

\section{Bevezetés}

Az éghajlatváltozással összefüggő fellépés és a tágabb értelemben vett környezetvédelem - amely magában foglal többek között preven tív kezdeményezéseket, valamint adaptációs és implementációs programokat egyaránt - sokszínú és változatos politikákat eredményezett: a magát a jelenséget is tagadó álláspontoktól egészen az annak megelőzése érdekében folytatott aktív tevékenységekig. A klímaváltozás kapcsán kialakult nemzetközi intézményi architektúra, amelynek bázisaként az 1992-ben elfogadott és az általában évente megrendezett találkozók révén folyamatossággal rendelkező riói keretegyezményt (United Nations Framework Convention on Climate Change, UNFCCC) tekinthetjüik, egészen a 2015-ben megalkotott párizsi egyezményig fejlődött, amely univerzális jellegével és az Amerikai Egyesüilt Államok részvételével újabb mérföldkőnek számított.

Míg Brazíliát erôteljes kritikák érték, és különböző félelmek hangzottak el az éghajlatváltozás érdekében tett vállalásai kapcsán (Fearnside, 2019), addig egyesek például Szingapúr optimizmusáról és vállalkozó szelleméről (Ang, 2016), mások a - fontosságát tekintve kiemelendő - Kínai Népköztársaság környezetvédelem iránti pozitív

Az 1972-es stockholmi konferencia (UN Conference on Human Environment) mellett. 
elkötelezettségéről (Chin-Yee, 2016), illetve a hatékony érdekérvénye sítés és multilateralizmus iskolapéldájának tekinthető Kis Szigetállamok Szövetségének (Alliance of Small Island States, AOSIS) relevanciájáról (Ourbak és Magnan, 2017), mindezek alapján pedig a párizsi egyezmény előremutató, „pozitív” eredményeiről értekeznek (ChinYee, 2016; Dimitrov, 2016).

2019. november 4-én azonban az Amerikai Egyesült Államok kor mánya az Egyesült Nemzetek Szervezetének főtitkárát a 2015. december 15-én elfogadott és 2016. november 4-én hatályba lépett párizsi egyezményből való kilépési szándékáról értesítette, s az az egyezmény 28. cikk 1. és 2. pontja értelmében 2020. november 4-én érvénybe is lépett. A Barack Obama elnök által aláírt egyezményt ugyanis utódja, Donald Trump aránytalanul károsnak ítélte: az adminisztrációja érvelése szerint az Egyesült Államok kötelezettségvállalásai túlságosan is nagyok és egyoldalúak, más országokét messze meghaladják, amivel előnytelen helyzetbe hozzák az amerikai ipart, ami pedig a versenyké pesség folyamatos romlását vonja maga után. Joseph Robinette Biden (ismertebb nevén: Joe Biden) választási győzelme viszont ismét for dulópontot jelentett, hiszen a hivatalba lépését követően számos új, a Trump-adminisztrációéval ellentétes klímapolitikai döntése között az egyezményhez való visszatérést is előirányozta.

Elemzésemben az egyezmény 2015-ös elfogadásának közvetlen előzményeitől a Trump által a főtitkárnak 2019-ben benyújtott értesítésig tartó periódus eseményeit tekintem át. Végső soron pedig arra kívánok rámutatni, hogy az egyezményből való - az addig elért amerikai sikerek ellenére történt - kihátrálás valójában Donald Trump konzekvens klímapolitikai döntéseinek a többé-kevésbé előre látható eredménye volt. Az első három fejezet az Amerikai Egyesüilt Államoknak mint a nemzetközi rendszer meghatározó szereplőjének, illetve az amerikai társadalomnak és belpolitikának az éghajlatváltozással összefüggő jellegzetességeit veszi górcső alá, azon belül is különösen a párizsi egyezménnyel kapcsolatos amerikai érdekérvé nyesítés eredményeit igyekszik feltérképezni. A negyedik fejezet az egyezményből való „kihátrálást” övező komplex társadalmi-politikai 


\section{Külïgyi Szemle}

folyamatokat kívánja megvilágítani. Mindebben a párizsi egyezmény vonatkozó pontjainak a vizsgálata, továbbá a szakirodalom és a résztvevők által tett nyilatkozatok, valamint a médiában megjelent cikkek és interjúk voltak segítségemre.

\section{Az Egyesült Államok és a nemzetközi klímapolitika elméleti megközelítése}

Az institucionalizmus vagy a funkcionalizmus ${ }^{2}$ szempontjából az in tézményesülés - jelen esetben egy multilaterális nemzetközi egyez mény létrejötte - valójában természetszerủ és racionális érdekköve tésre vall. Az államok a kollektív fellépéssel járó előnyök miatt for dulnak az uni- és bilateralizmus helyett a multilateralizmus eszköz tárához. Az intézmények terjedésétől, vagyis egy átfogó klímaegyez mény megalkotásától az amerikai érdekérvényesítési képesség és a külpolitikai mozgástér feltételezhetően növekszik - ezért a haszonmaximalizálás konfrontatív jellege és a hatalomért folytatott harcból adódóan a nemzetközi rendszerben kialakuló konfliktusok ellenére az Egyesült Államok célja az együttmúködés erősítése, a transznacionális kapcsolatok révén pedig a stabilitás és az interdependencia növelése. A klasszikus liberalizmus magyarázata alapján pedig abból indulunk ki, hogy a nemzetközi rendszert meghatározó törékeny béke stabilitásának, valamint a környezetvédelem területén keletkező jogi kötelezettségeknek a megerősítése éppen a nemzetközi szerződések elterjesztésével, a nemzetközi intézményi rendszer szélesítésével kivitelezhető.

Mindezek ellenére úgy gondolom, hogy a liberális-institucionalista modell nem veszi figyelembe a szereplők közti különbségeket. Így nem szentel kellő figyelmet például az Egyesüilt Államok hatalmi pozíciójának, a Kínai Népköztársasággal való versenyhelyzetének vagy a nemzetközi rendszerben betöltött szerepéből adódó saját érdekeinek.

2 A liberális institucionalizmus képviselői között emnlíthető például Robert Keohane. a funkcionalizmus kapcsán pedig az irányzatot megalapító David Mitrany. 
Ennek megfelelően csupán az egyezményt eddig ratifikáló 188 állam³ egyikeként szerepel az elemzésben. Továbbá nem számolunk azzal a ténnyel sem, hogy éppen az USA az egyik legnagyobb kibocsátója azoknak a gázoknak, amelyek csökkentése érdekében az egyezményt életre hívták, vagyis e szemlélet értelmében az amerikai gazdasági érdekek a hosszú távú, globális környezeti érdekek árnyékában elveszítik a jelentőségüiket.

Többek között a Gilpin-féle realista modell (Gilpin és Gilpin, 2001) alapján szintén azt láthatjuk, hogy az Egyesült Államok racionális megfontolásokból az 1990-es éveket követően kialakult unipoláris rendszerben - hegemónként - is kész volt elköteleződni egy olyan globális szerződés megkötése iránt, mint a párizsi klímaegyezmény. Tette ezt azért, mert a nemzetközi rendszerben betöltött pozíciójánál fogva érdeke volt, hogy elősegítse és elkötelezettségét fejezze ki egy olyan globális, közérdekủ és kollektív fellépést igénylő területen, mint az éghajlatváltozás. A realista modell értelmében a párizsi egyezmény esetében sem történt másképp, mint hogy az államok - a nagyhatalmi szerepénél fogva pedig kifejezetten az Egyesült Államok - érdeke azt diktálja, hogy a versenytársai(k) tevékenysége, valamint a nemzetközi rendszer egésze kiszámíthatóbbá, átláthatóbbá váljon, s így az érdekeit a kockázatok hatékony felmérése és minimalizálása mellett tudja érvényesíteni. Ráadásul a párizsi egyezményen kívüil maradás a fejlődő államok irányába folyó transzferek ellenőrzésének, valamint a klímavédelem kapcsán felmerülő irányítási, támogatási és ellenőrzési lehetőségeknek az elszalasztását is eredményezheti.

Amennyiben az Egyesült Államok mindenkori elnöke és kormánya valóban elkötelezett az egyezményben foglaltak bizonyos mértékủ adaptálásában és a betartás, betartatás ellenőrzésében, akkor az amerikaiak kimaradása éppen hogy kontraproduktív, hiszen egy ilyen lépés precedensként szolgálhat más államok számára, és az éghajlatvédelem iránti elköteleződés csökkenését, a célok elérése iránt optimista országok részéről pedig az egyedül maradás érzését, az USA

3 2020. november 11-én, az amerikai kilépés után ellenőrzött adat (United Nations Treaty Collection, é. n.). 


\section{Külïgyi Szemle}

támogatásának az elvesztését, s így a szövetségesi-partneri viszonyok szimbolikussá válását okozhatja. Hogy egy nemrég zajlott eseményre utaljunk: ha a Krím félsziget annexiója idején tapasztalt amerikai következetlenség és gyengekezúség nem lett volna elég (még ha az az Obama-adminisztráció alatt történt is), az amerikaiak szövetségeseinek a Trump által gyakorolt vécőháló-visszahúzás kapesán kialakult félelmei egy új területtel bővüllhetnének, amely - a hegemónciklusok elméletét idézve - talán az Egyesült Államok érájának hanyatlását egy új perspektívából világíthatja meg.

Annak ellenére tehát, hogy a realista megközelítés szerint az Egyesült Államoknak csakugyan érdekében állna, hogy a hitelességét és az elkötelezettségét fenntartsa egy ilyen, globális, nemzetközileg széles körben elfogadott és támogatott egyezménnyel kapcsolatban, úgy tűnik, hogy a Trump-adminisztráció szerint a szerződéses kompromisszumok felmondása a nagyobb hasznok reményében, ha csak rövid távon is, de kifizetődóbb döntés volt.

Az éghajlatváltozás folyamata újabb és újabb kihívásokkal állítja szembe az államokat. A tengerszint emelkedése és a szélsőséges időjárási körülmények a geostratégiailag jelentős területek, szigetek átalakulását és jövőbeli eltűnését okozhatják. Ez utóbbi pedig - elsősorban az esetlegesen hontalanná váló tömegek révén bekövetkező migrációs és humanitárius válság okán - az állami szuverenitás és közvetlenül a nemzetközi rend és biztonság stabilitását veszélyeztetheti (Habib, 2015; Werrel és Femia, 2016). Ezért e globális kihívások a nemzetközi együittmúködés erősítését, a nemzetközi jogi környezet átalakítását és újragondolását, az államiságra vonatkozó reguláció rugalmasabbá tételét teszik szüikségessé (Rayfuse és Crawford, 2011). Ennek ellenére - részben az esetleges gazdasági hátrányok miatt - jelenleg az amerikai érdekekkel összeegyeztethetetlennek tűnik az éghajlatváltozásból, azon belül a tenger szintjének az emelkedéséből adódó partvonalváltozások okozta tengeri határok megváltoztatása, a nemzetközi jogban meghatározott parti tengerek mellett például a különleges gazdasági övezetekre vonatkozó jogi szabályozás átalakítása. ${ }^{4}$

4 Az állam területének elvesztése, a szuverenitáskoncepció átalakulása, valamint az 
Az államközi konfliktusok és érdekütközések ellenére mégis egyre inkább elfogadottá válik az az álláspont, miszerint e globális kihívás leküizdése kizárólag multilaterális keretek között sikerülhet. Viszont ha a nemzetközi közösség kész felvállalni, hogy kollektív felelősség terheli az éghajlatváltozás következményei miatt, különösen az annak leginkább kitett államok és társadalmak kontextusában, akkor a vesztfáliai béke óta létezỏ szuverenitáskoncepcióval kapcsolatban olyan kihívásokkal kell szembenéznie, mint a tengerszint emelkedése következtében terület nélkül maradt államok népességének a befogadásáért, a státuszuk rendezéséért való felelősségvállalás.5 A nemzet közi közösség felelősségének a rögzítése bizonyos esetekben egy, az egyébként vitatott legitimitással bíró humanitárius intervenció gyakorlatához hasonló beavatkozás lehetőségét is felveti, ugyanis az ez utóbbi kapcsán tapasztalt gyakorlatot a Robyn Eckersley által bevezetett, ún. „ökológiai védelmi felelősség elvével” (ecological responsibility to protect) és az „ökológiai intervenció” (ecological intervention) fogalmával egészítheti ki (Eckersley, 2007), s ezzel még bonyolultabbá teheti az állami szuverenitás témakörét és egy esetleges beavatkozás lehetőségének a feltételrendszerét. ${ }^{6}$

A fentiek ellenére a Trump vezette republikánus adminisztráció az elmúlt bő négy évben éppen a hagyományosan értelmezett nem zeti szuverenitás visszaszerzésének a szükségességét hirdette (lásd például: Halper és Zavis, 2017). Mindeközben pedig az éghajlatváltozás következményei és azok kezelésének a lehetőségei a jellegüiknél fogva különösen alkalmasak az institucionalisták alkotta spillover hatás kiváltására, s így éppen hogy mind szorosabb nemzetközi együttmúködést feltételeznének számos más területen is (gondolhatunk

éghajlatváltozás, különösen a tengerszint emelkedése során felmerülő nemzetközi jogi kihívások és megoldások komplex összefüggéseiről bővebben lásd: Rayfuse és Crawford, 2011.

5 E felelősségvállalás pedig legitimálná az úgynevezett „klímamenekültek” létét és védelemhez való jogát, valamint az ezzel járó költséges programok végrehajtását (Arcanjo, 2019).

6 A védelmi felelősség (Responsibility to protect) elvének például a koronavírus-járvány nyal kapcsolatos relevanciájáról és az elvet érintő fogalmi keretek kiterjesztésének a szüikségességéről lásd részletesebben: Marton és Hoffmann, 2020. 


\section{Külïgyi Szemle}

itt például a multi- és transznacionális vállalatok szabályozására) (Eckersley, 2007). Ez azonban szintén nem élvezett prioritást a re publikánus, izolacionista külpolitikai vonalvezetésben.

\section{Az amerikai társadalom, belpolitika és az éghajlatváltozás összefïggései a párizsi egyezményt megelözố években}

Amennyiben a társadalom egészére kivetítve és nagyobb időszakra vonatkozóan szeretnénk következtetést levonni az amerikaiak éghajlatváltozással kapcsolatos attitűdjéről, elsőként kiemelendő, hogy míg a társadalom több mint fele (52\%) 2007 tavaszáig előnyben részesítette a környezetvédelmet és az ahhoz kapcsolódó politikákat, addig a 2008-as válságot követő adatok már épp az ellenkezőjét mutatták, azaz a gazdasági stabilitás helyreállítása prioritást élvezett a gondolkodásukban (Russonello, 2015). Ez pedig az egyén szintjén rávilágíthat a gazdasági konjunktúra és recesszió, illetve a környezetvédelem iránti elkötelezettség közötti összefüiggésekre.

George Monbiot az éghajlatvédelemmel foglalkozó koppenhágai találkozó sikertelenségének okai közt már közvetlenül a gazdasági válságot követően az amerikai belpolitikát, az ipari érdekeltséggel ren delkező demokraták szenátusi hányadát és az elnök felszínes tevékenységét említette (Monbiot, 2009). Néhány évvel később, 2015-ben, az amerikai energiaipar védelmének érdekében a szenátusi döntéshozatal politikailag vállalhatatlannak tartotta - a kiotói és koppenhágai folyamathoz hasonlóan - egy szigorúbb verifikációs rendszerrel és jogi kötőerôvel rendelkező egyezmény elfogadását (Falk, 2016). A The New York Times és a CBS News adatai alapján Russonello viszont rávilágított arra, hogy mindeközben az amerikai társadalom 63 százaléka támogatta volna egy kötelezô érvényű nemzetközi egyezmény megkötését, ráadásul a republikánusok többsége is e mellett foglalt állást (Russonello, 2015). ${ }^{7}$

\footnotetext{
7 Az ellenzők között muszáj megemlíteni a társadalom azon tagjait, akik csupán nagyrészt a hagyományos ipari - főleg a szénbányászat által teremtett
} 
A republikánus szavazók kezdeti szimpátiája ellenére a Republikánus Párt kongresszusi képviselőinek a többsége (Goldenberg, 2015a), valamint egyes szenátorok kifejezetten tiltakoztak Barack Obama egy ilyen egyezmény megalkotására vonatkozó törekvései ellen. Mindezt úgy, hogy akkoriban az amerikaiak 75 százaléka amellett foglalt állást, hogy a globális hőmérséklet-növekedés súlyos környezeti következ ményekkel jár vagy fog járni a jövőben (Russonello, 2015). ${ }^{8} \mathrm{E}$ téren ismét megmutatkoznak a pártközi diszkrepanciák: míg a demokraták közül tízből kilencen a globális felmelegedés súlyos hatásaira hívták fel a figyelmet, addig a republikánusoknak csupán 58 százaléka vélekedett így; mi több, egyharmaduk kifejezetten elutasította, hogy a hőmérséklet-növekedés bárminemủ következménnyel járna a környe zetre (Russonello, 2015).

Mindezekből kitűnik az a problémakör, amit egy átfogó nemzet közi egyezmény elfogadásával kapcsolatos belpolitikai feszültség jelent. Itt érdemes megemlíteni például Mitch McConnell republikánus politikus, Kentucky állam jelenlegi szenátorának az Obama elnököt a kötelezettségvállalásai miatt illető kritikáját. De felidézhetjük Jim Inhofe, a környezetvédelemmel foglalkozó akkori szenátusi bizottság - republikánus - elnökének (Chair of the Senate Environment Committee) a további vizsgálatra való igyekezetét is, amellyel egyesek szerint az elfogadásra váró nemzetközi egyezmény aláaknázására törekedett (Goldenberg, 2015b).

Az Obama-adminisztrációnak ilyen belpolitikai környezetben kellett sikerre vinnie a párizsi egyezmény elfogadását, amihez a részt vevő felektől kiemelt politikai tôkemozgósításra, a multilaterális tárgyalások mellett folyamatos bilaterális kapcsolattartásra és

munkalehetőségek közül választhatnak, s az átképzésük, más iparágakra történő be tanításuk korlátozott lehetőségekkel bír (Brewer és Golden, 2016).

8 A társadalmi összefüiggések kapcsán megemlíthetjük még, hogy az amerikaiak egy jelentős hányada az adóemeléssel is együtt járó adóreform helyett inkább az üzleti tevékenység korlátozásával kívánta és kivánja az éghajlatváltozás hatásainak a csillapítását elérni. Ők szintén egy, az e területen belpolitikai értelemben restriktív politikát indukáló nemzetközi egyezmény mellett foglaltak állást, annak ellenére, hogy például a bányászat, a fa-és az ásványkitermelés kapcsán a demokraták véleménye is megosztott volt (Russonello, 2015). 


\section{Külïgyi Szemle}

konzultációra volt szükség. Az amerikai környezetvédelmi lobbi eró teljes tevékenysége mellett (Goldenberg és Roberts, 2015) például azt az esetet is megemlithetjük, amikor Michael Bloomberg (New York először demokrata, majd republikánus színekben, végüil függetlenként politizáló polgármestere) igyekezett meggyőzni a vállalatok vezetőit egy átfogó nemzetközi egyezmény támogatásáról. (Goldenberg, 2015b).

\section{A Párizsig vezetô út és az egyezmény értékelése}

A párizsi egyezmény megalkotásának sikerében - a tárgyalások kiértékelése alapján - Radoslav S. Dimitrov ${ }^{9}$ fontos elemként egyrészt az évek során kialakult társadalmi tanulást és fejlődést, a hatékony meggyőző érvelés technikáit, másrészt az Egyesült Államok és Kína között 2014-ben létrejött bilaterális megállapodást (The White House, Office of the Press Secretary, 2014) említette - ez utóbbit a Párizsban elért siker egyik ugródeszkájának tekintette (Dimitrov, 2016).

Barack Obama, aki felismerte az éghajlatváltozás globális jelen tőségét, a második ciklusa egyik vezérfonalaként határozta meg az ellene folytatandó küzdelmet, valamint a szennyezőanyag-kibocsátás csökkentését (Goldenberg, 2015b). A személyes elköteleződése olvas ható ki például a 2015. november 30-án elmondott párizsi beszédé bôl is (The While House, Office of the Press Secrelary, 2015a), amelyben többek között a kollektív nemzetközi fellépés szüikségessége, a szennyező anyagok kibocsátásának visszaszorítása, a globális hőmérséklet-növekedés csökkentése, valamint a megújuló energiaforrások felé való eltolódás és az ahhoz kapcsolódó iparágakba történő, növekvő számú befektetés iránti elkötelezettségét hangsúlyozta. Kiemelte, hogy a világ (akkori) legnagyobb gazdaságának és a második ${ }^{10}$ legnagyobb szennyezőanyag-kibocsátó országának a vezetőjeként a

9 Radoslav S. Dimitrov a párizsi egyezmény megalkotásának folyamatában közvetlenül részt vett, és az ott megfigyeltek alapján kifejezetten a meggyőző erỏ képességét és a szervezeti taktika eszközeit állította a vizsgálata középpontjába a politikai, diplomáciai folyamatok mélyebb megértésének kulcsfontosságú tényezőiként.

10 Ez napjainkban is érvényes (Global Carbon Atlas, 2019). 
megállapodások és tárgyalások eredményeként az amerikai fél részé ről tett vállalások teljesítéséhez minden feltételt kész biztosítani.

Az Obama-adminisztrációnak az éghajlatváltozás leküzdésére irányuló progresszív tevékenységét jelzi az említett, 2014-ben kiadott közlemény (The White House, Office of the Press Secretary, 2014) és a 2015-ben megjelent közös amerikai-kínai nyilatkozat (The White House, Office of the Press Secretary, 2015b) is. Az, hogy a Parizsban kicsúcsosodott folyamat iránti elköteleződés és az éghajlatváltozás visszaszorításának sikere amerikai érdek, az olyan korábbi kezdemé nyezésekből is kitűnik, mint a szintén amerikai-kínai relációban megvalósuló városi szintű együittmúködések" (H. F. Li, 2016), illetve a közös munkacsoport (U.S.-China Climate Change Working Group, CCWG), a közös kutatóközpont (U.S.-China Clean Energy Research Center) és a közös stratégiai és gazdasági dialógus (U.S.-China Strategic and Economic Dialogue) létrehozása. Mind az amerikai elnök, mind az akkori külügyminisztere, John Kerry optimista álláspontot képviselt, és várakozva tekintett a párizsi tárgyalásokra (Davenport, 2015). Ez nem véletlen, hiszen a kínai és a vendéglátó francia delegáció tagjai az amerikai kulesszereplőkkel együittműködésben már a találkozót megelőzően azon dolgoztak, hogy a rendezvény végén elfogadandó egyezményt már az elején vonzóvá tegyék a nemzetközi közösség előtt, és eloszlassák a felmerüilő kételyeket (H. F. Li, 2016).

Ilyen előzmények után fogadták el 2015. december 12-én a párizsi egyezményt, amelynek a célja a kollektív felelősségvállalás, a környezetkárosító gázok kibocsátásának és az átlaghőmérséklet-növekedés folyamatának a csökkentése, valamint az éghajlatváltozás természe ti jelenségek formájában megnyilvánuló következményeinek és hatá sainak az enyhítése a fejlett és a fejlődő államok összefogása révén. Az egyezmény elfogadásán túl Barack Obamának azt is sikerült elér nie, hogy a nemzetközi egyezmény jogi kötőereje olyan testet öltsön, amely a szenátusi ratifikáció nélkül is lehetővé teszi az egyezményhez való csatlakozást. Ezzel, valamint a hatályba lépéshez szüikséges aláírói küiszöbérték 2016 novemberéig - vagyis az amerikai elnökválasztásig -

11 Bővebben lásd: Sina, 2015 


\section{Külïgyi Szemle}

történő teljesítésével a demokrata elnök azt is elérte, hogy egy repub likánus győzelem esetén az új elnök csak az előírt hároméves perió dus letelte után léptethesse ki az Egyesült Államokat az egyezmény hatálya alól.

Míg a Rióban elfogadott 1992-es UNFCCC inkább általános poli tikai felelősségvállalásként került be a nemzetközi egyezmények sorá ba, addig az 1997-es kiotói jegyzőkönyv már a fejlett és a fejlődő álla mok közötti kapacitáskülönbségeknek valódi relevanciát kölcsönzött, és a szigorúbb differenciálás alapjainak a lefektetésével megalapozta ${ }^{12}$ a 2015-ös megállapodás két kulcskérdésének - az ez irányú küilönb ségtételnek, valamint a transzfereknek (technológia és pénz) - a témakörét. ${ }^{13}$ Ezek pedig 2015-ben meghatározó pontjai voltak az amerikai stratégiának is.

A párizsi egyezmény egy négyéves tárgyalási folyamat eredménye ként, kompromisszumkész légkörben született meg. Az egyeztetések meghatározó eleme volt, hogy az ülésekről teljes mértékben hiányoz tak a civil társadalom képviselói, a második heti megbeszéléseken a legtöbb kormány delegációja már nem vehetett részt, és csupán de legációnként négy személy ülhetett a tárgyalóasztalhoz (Dimitrov, 2016). Ez alapvetően kérdőjelezhette meg a multilateralizmus által biztosított transzparenciába vetett hitet.

A párizsi egyezményhez füzött nemzeti vállalások (Intended Nationally Determined Contributions) hipokrita jellegétől és a korai optimizmustól tartott például Lomborg (2015). Egyesek a következő részben részletesebben tárgyalandó „szerkesztési csavarok” közüil az egyezmény 9. cikk 1. pontjában szereplő engedékenyebb szövegezésre $^{14}$ utalva fogalmaztak meg további kritikát, mivel az többek között

12 Ez a „közös, de megkülönböztetett felelősségek elve” (a szerző fordítása), amely a párizsi egyezmény 2. cikk 2. pontjában is olvasható: „This Agreement will be implemented to reflect equity and the principle of common but differentiated responsibilities and respective capabilities, in the light of different national circumstances."

13 A differenciálás témakörét részletesen feldolgozza: Rajamani, 2016, 493-514. o.

14 9. (1) „Developed country Parties shall provide financial resources to assist developing country Parties with respect to both mitigation and adaptation in continuation of their existing obligations under the Convention." E pontban az .Each delevoped country 
az Egyesült Államok bizonyos értelemben öncélú érdekérvényesítését tükrözi (Bodansky, 2016). Mások egy esetleges amerikai kivonulás lehetőségének a következményeiről, vagyis a kollektív fellépést jelképező párizsi egyezményben keletkező vákuumról és veszélyekrôl értekez tek (Falk, 2016; Henry, 2017), de olyan is akadt, aki a kínai dominancia erősödéséről és a befolyásszerzés lehetőségeiről írt (Henry, 2017).

Annak ellenére, hogy a párizsi egyezmény az éghajlatváltozás terén korszakhatárként is felfogható, s az államok széles körủ részvétele miatt a multilateralizmus egyik előremutató vívmányának is tủnik, valójában nem mentes az állami önérdek-érvényesítés olykor destruktív következményeitől sem. A Párizsban elért kompromisszumok az úgynevezett „globális Észak”, avagy a „fejlett és iparosodott” államok szá mára biztosítottak előnyös pozíciót, azon belül is elsősorban az Amerikai Egyesült Államoknak, amely a sikeres koalícióépítési törekvésein és érdekérvényesítésén keresztül meghatározta az egyezmény arculatát, s így az sok esetben az amerikai érdekek és preferenciák mentén alakult ki (Parker és Karlsson, 2018). Míg a kiotói jegyzőkönyvet 1992 ben az Egyesüilt Államok Szenátusa 95:0 arányban elutasította, s egy nyilatkozatban (Congress.gov, 1997) deklarálta az amerikai szerepvál lalás korlátait a nemzetközi klímavédelem kapcsán teendő erőfeszíté sek terén, addig - ahogyan korábban említettem - 2015-ben Barack Obama politikai manôverezése a republikánus ellenállás ${ }^{15}$ ellenére is lehetôvé tette, hogy az ország szenátusi ratifikáció nélküil, pusztán a kongresszus jóváhagyásával (ún. presidential-executive agreement ré vén) csatlakozhasson a párizsi egyezményhez (Kemp, 2016).

Parties” helyett szereplö "Developed country Parties” kifejezés kollektív jellege nem egyénileg kötelezi az államokat a hozzájárulás és a támogatás biztosításáról, s így a jogi kötelezettség felhígulását eredményezi, például Bodansky (2016) szerint.

15 Két republikánus képviselő, Mike Lee és Mike Kelly például felszólította az elnököt. hogy véleményezésre és ratifikációra nyújtsa be a szövegtervezetet és a végleges megállapodást a szenátus elé (Kemp, 2016). 


\section{Külïgyi Szemle}

\section{A párizsi egyezmény amerikai perspektívából}

Elsősorban azt fontos megjegyezni, hogy a tárgyalások során nemcsak a "fejlett-fejlődô" relációban, hanem az úgynevezett "globális Észak”, vagyis a "fejlett Nyugat” államai között is adódtak súrlódások. Ilyen ütközési pontnak számított például a leendő egyezmény kötelező jogi erejére vonatkozó kérdéskör. Ebben az AILAC (Latin-Amerika országai közötti koalíció), az AOSIS és a Kínai Népköztársaság mellett az Európai Unió is egy viszonylag szigorú utókövetési mechanizmus, valamint a kitűzött célok és vállalások kötelezỏ teljesítése mellett foglalt állást. Eközben az Egyesült Államok, amely retorikájában hitet tett a hosszú távú célok teljesítésén túl a bizonyos területeken alkalmazandó kötelező jogi erô mellett is (Goldenberg, 2015a), valamint tagja volt annak a százfős csoportnak (High Ambition Coalition, HAC), amely szintén ezek mellett foglalt állást (Chin-Yee, 2016; Mathiesen és Harvey, 2015) - habár a nyilt szembehelyezkedés elkerülésének igényével valójában éppen az ellenkezőjében volt érdekelt. Nem véletlen, hogy az Egyesült Allamok agitációja következtében a végső szövegezés során - egy szócsere segítségével - csökkent a részt vevô államoknak a klímavédelem enyhítésére vonatkozó kötelezettségvállalásainak a jogi kötőereje (Chin-Yee, 2016; Dimitrov, 2016). Így ez is egyike lett azoknak a témaköröknek, amelyek kapcsán az amerikaiak nem voltak hajlandóak további engedményeket tenni (red line), s végül az érdekeiknek megfelelően került bele a végső szövegbe. Ezzel viszont olyan szereplőket negligált a döntés, mint például az egyezmény egyik legnagyobb vesztesének tartott $A \mathrm{GN}$, az afrikai államokat tömörítő csoport (African Group of Negotiators) (Chin-Yee, 2016).

A tárgyaló felek közötti további ellentétként és egy újabb red lineként fogható fel a kifejezetten a fejlődő államok részéról megfogalmazódott követelés, amely az egyezmény 8. cikke kapcsán merült fel. Ez az ún. „veszteség és sérelem"16 (loss and damage) tekintetében deklarálta volna a fejlett, iparosodott államoknak az éghajlatváltozásban

16 A szerző fordítása. 
való kiemelt felelősségét, továbbá az „éghajlat-igazságosság”"17 (climate justice) koncepciójával egyértelmúsítette volna a mai fejlődő régiók lehetőségeinek a történelem során a fejlett államok által történt kihasználásukból eredően korlátozott voltát. Mondani se kell, hogy az Egyesüilt Államok ellenzett minden olyan utalást, amely az éghajlat változással összefüggésben az amerikai vállalatok jogi vagy pénzügyi felelősségét lett volna hivatott megállapítani (Chin-Yee, 2016). Leisha Beardmore, a Seychelles-szigetek tárgyalódelegációjának elnöke szerint például az amerikai álláspont egyértelmű volt: a fejlődők túlzott mértékủ követelése a tárgyalások sikerének a rovására mehet, s elle hetetlenítheti egy átfogó egyezmény elfogadását (Goldenberg, 2015b). Nem véletlen, hogy a 8 . cikk végül semmiféle utalást nem tartalmaz a fejlett államok felelősségére vonatkozóan. Emellett, ha azt is figye lembe vesszük, hogy az egyezményhez csatolt dokumentumok közül az egyik határozat nyíltan kifejezi, hogy a 8. cikkben foglaltak sem milyen felelősség és abból eredő kompenzáció megállapítását nem teszik lehetővé, egyértelmúvé válik az amerikai érdekérvényesítés hatékonysága és sikeressége (Ourbak és Magnan, 2017; Chin-Yee, 2016).

Az előbbiekben ismertetett folyamatokhoz hasonlóan végződött az afrikai államokat tömörítő AGN csoport azon kezdeményezése is, amely a fejlett államok részéról nyújtandó támogatások 50-50 százalékos megosztását tûzte ki célul. E szerint a befolyó pénz egyik része a környezetváltozáshoz való adaptációt segítő, a másik pedig az ég hajlatváltozást súlyosbító szennyezőanyag-kibocsátás enyhítését cél zó programokra irányult volna. Ez kulcskérdésnek számított a fejlődő, kifejezetten pedig az afrikai államok számára, hiszen így biztosították volna, hogy amennyiben a nagyobb kibocsátó országok - például az Egyesült Államok - az enyhítésre vonatkozó vállalásaikat nem telje sítenék, az emiatt súlyosbodó környezeti körüilményekhez való adap tációs politikákra fordítható összegek mindenképpen megérkezzenek (Chin-Yee, 2016).

A dekarbonizáció kapesán az Egyesült Államok a határozatlan idejű, a konkrét számokat negligáló felelősségvállalást támogatta. Mi

17 A szerző fordítása. 


\section{Külïgyi Szemle}

több, az általa preferált 2 fokos hőmérséklet-növekedés érdekében a száznál is több állam által előirányzott - a fejlődő és a legkevésbé fejlett államok (Least Developed Countries, LDC) által forszírozott (Monbiot, 2009) - koncepciót, vagyis az évszázad végére elérendó 1,5 fokos hőmérséklet-növekedési célt is elutasította. Határozott aggályokat fogalmazott meg ez utóbbival szemben, s egy, annak a követ kezményeit elemző bizottsági jelentés elkészitését is megakadályoz ta - Kínával, Indiával és Iránnal egyetértésben (Dimitrov, 2016). Az ezzel összefüggő probléma akkor válik nyilvánvalóvá, ha tudjuk, hogy az ENSZ szerint a nemzeti vállalások teljes körű teljesítése esetén is nemhogy a 1,5, de még a 2 fokos növekedés is teljesíthetetlennek célnak számított az általa prognosztizált 2,7 fokos emelkedés árnyékában (Harvey, 2015).

\section{A Trump-adminisztráció és a kivonulás politikája}

Donald Trump a megválasztását követően, már a 2017. januári hivatalba lépésének kezdetén nekilátott az Obama-féle klímapolitika felülvizsgálatának. A párizsi egyezménnyel kapcsolatban a republikánus kormányzat előtt álló lehetőségek korlátozottak voltak. Az egyik út az volt, hogy a kampányígéretek ellenére teljesítik a szerződésben vállaltakat, kockáztatva, hogy azzal a Republikánus Párt elveszítheti a szavazóbázisa egy részét, a másik értelmében az ország továbbra is részes fél marad az egyezményben, azonban nem teljesíti a vállalt kötelezettségeket. Ez utóbbi azonban többek között az Egyesült Államok nemzetközi megítélésének a romlásával, s a külkapcsolatai egy részének a megingásával járt volna (Kemp, 2016). A harmadik megoldás, a párizsi egyezményből való kilépés szintén a súlyos nemzetközi presztízsvesztés kockázatát hozdozta. Azzal, hogy Donald Trump lett az elnök, már a terminusa elején világossá vált, hogy Washington a harmadik, a kivonulás mellett kötelezi el magát. Ezt az adminisztráció első ízben már 2017. június 1-jén bejelentette, az ENSZ főtitkárát azonban hivatalosan csak az egyezmény elfogadását követő hároméves átmeneti időszak letelte után, 2019. november 4-én értesítette 
az amerikai elnök. A kivonulásra vonatkozó döntés irányába mutató jelek azonban már 2017 tavaszán láthatóvá váltak.

Az Obama által 2015 augusztusában bejelentett clean power plan konstrukció (Natural Resources Defense Council, 2017), amelynek célja a szén-dioxid kibocsátásának a csökkentése volt, már a demokrata kormányzás alatt éles belpolitikai vitákat gerjesztett. A szövetségi és az állami hatáskörök szétválasztásán is alapuló, a decentralizáció jegyében kitűzött dekarbonizációs célok eléréséhez az államok számára széles körû tervezési lehetőséget biztosító szabályozás már a kezdetekkor több tucat cég mellett a republikánus kormányzók által vezetett államok támadásainak is a kereszttüzébe került (Milman, 2016). A demokrata kormány célja e koncepcióval nem volt más, mint a párizsi egyezményben foglalt vállalásoknak való megfelelés, a levegô minőségének a javítása, a környezet védelmét is figyelembe véve új munkahelyek teremtése, valamint az energiaipar, vagyis a megújuló energiaforrásokra történő átállás támogatása volt (Davenport és Rubin, 2017). Ezzel kapcsolatban a Trump-adminisztráció korábbi kritikáinak a gyakorlatba való átültetése az elnökválasztást követően már 2017 márciusában elkezdődött. A Környezetvédelmi Hatóság (Environmental Protection Agency) új, 2017 és 2018 közötti - republikánus - igazgatója, Scott Pruitt szembehelyezkedett az Obama-féle állásponttal: az elejétől fogva igyekezett aláásni az említett kezdeményezést (Henry, 2017), később pedig támogatta mindazokat a törekvéseket is (Green, 2019), amelyek az arra vonatkozó szabályozás feloldása mellett a Párizsban tett vállalások és kötelezettségek visszavonására irányultak (Pengelly, 2017).

Szintén a párizsi egyezményből való kivonulás egyik előjeleként ér telmezhető az Obama által bevezetett ïzemanyag-hatékonysági követelmények (fuel efficiency standards) rendszerének eltörlésére irányuló republikánus törekvés, amely maga mögött tudta az újonnan „megreformált"18 Környezetvédelmi Hatóság mellett az autóipari lobbi teljes

18 Viszonylag bevett gyakorlatnak számított (a vizsgált időszakban legalábbis mindenképpen), hogy a demokraták, illetve a republikánusok választási győzelme egyúttal a Környezetvédelmi Hatóság esetében is egyfajta politikai szemléletváltást ered ményezett, így annak véleménye általában illeszkedett az éppen kormányzó párt 


\section{Külïgyi Szemle}

támogatását (Milman, 2017) is. Kiemelendő az olaj, illetve a szénipar lobbija is, amely a környezetvédelemmel összefüiggő esetleges meg szorítások, szabályozások terén igen releváns befolyásoló képességgel rendelkezett és rendelkezik a mai napig. Ez szembetűnő, ha azt vesszük, hogy egyes számítások szerint az olajipari lobbihoz kerülő minden egyes dollár 119 dollárnyi összegben térül meg (Oil Change Internatonal, é. n.). A szénipari lobbisták közül pedig elég, ha Robert Murrey nevét említjük, aki az egykoron legnagyobb - 2019-ben azonban csődöt jelentett -, magánkézben lévő vállalatán ${ }^{19}$ keresztül (Taddonio, 2019) Trump egyik támogatója volt, és az éghajlatváltozás tényének egyik elutasítójaként, az egyezményből való kilépés mellett emelt hangot (Johnson, 2019).

Ugyanakkor az Egyesült Államok diplomáciai kapcsolatainak a védelme és a globális klímavédelem érdekében például Rex Tillerson - az Exxon Mobil korábbi vezetője és Donald Trump külüigyminiszte re 2017 és 2018 között - a Párizsban tett vállalások fenntartása mel lett emelt szót, sőt az elnök lánya, Ivanka Trump is az egyezmény mellett foglalt állást (Johnston, 2017a; Johnston, 2017b). Marc Morano korábbi republikánus szenátor szerint ők jelenthették a legnagyobb akadályt az Egyesült Államoknak az egyezményből való kivonulása előtt (Johnston, 2017b). A Demokrata Párttól és a nemzetközi közös ségtől érkezett kritikák ellenére a Trump-adminisztrációnak az éghajlatváltozás terén megfigyelt kül-és belpolitikai vonalvezetése arra engedett következtetni már nem sokkal a 2017-es beiktatás után, hogy Barack Obama öröksége - legalábbis a klímapolitika, azon belül is a párizsi egyezmény tekintetében - nem marad fenn a demokrata ciklust követően (Goldenberg, 2015a).

Donald Trumpnak a sok esetben - akár az amerikai-kínai ha talmi versengéssel és a kínai vállalások elégtelenségével kapcsola tosan - elhangzott, impulzív retorikai eszközökkel operáló beszé dei ellenére az egyezményből való republikánus kihátrálás egy több

\footnotetext{
klímapolitikai koncepciójába.

19 Murrey Energy Holdings Company.
} 
évet felölelő, folyamatos, konzekvens politika következménye volt (U.S. Department of State, Office of the Spokesperson, 2017). Ennek egyik bizonyítéka lehet, hogy 2017 augusztusában a külügyminisztérium még a környezetvédelmet egy, az energiabiztonságot és a gazdasági növeke dést hangsúlyozó politikai irányvonal egyik további fontos elemeként rögzítő nyilatkozatot adott ki.

Kérdéses volt azonban, hogy egy ilyen, az Egyesült Államokon be lïl is széles körben elfogadott ${ }^{20}$ egyezmény milyen mértékben veszít het a hitelességéből, és mennyiben akadályozhatja a benne foglaltak teljesítését és a részt vevő országoknak (lásd például az EU vonatkozásában: Reuters, 2017) a vállalásaik iránti elköteleződését ${ }^{21}$ az, hogy az egyik legnagyobb szennyezőanyag-kibocsátó ország, egyúttal a párizsi tárgyalások során az Európai Unió és Kína mellett a harmadik ${ }^{22}$ legmeghatározóbb kulcsszereplő (Parker és Karlsson, 2018) kivonja magát annak hatálya alól.

Mivel a párizsi egyezmény nem tér ki a nem részes államok fele lősségére, sem a szubnacionális aktorok - ebben az esetben az amerikai államok - lehetôségeire, valamint a 28. cikk lehetővé teszi az egyezményből való kilépést, Luke Kemp már 2016-ban egy esetleges kivonulás lehetőségérôl és annak kezelési technikáiról írt. Emellett az esetleges szankcionálás módjaiól, vagyis a büntetés, a könnyítés, a

20 Az Egyesült Államok kormányának kilépésére egyfajta társadalmi-politikai válaszként említhető például az akkoriban majdnem mind az 50 tagállam lakosságából összesen 160 millió főt, számos intézményt és vezetőt tömörítő kezdeményezés, a We Are Still In (é. n.), amelyben ma már ismét a teljes USA benne van.

21 Félő volt ugyanis, hogy egyes államok kilépése után a játékelmélet egyik klasszikus példája, a közlegelők tragédiája fogja értelmezhető keretként meghatározni más részes államok klímavédelmi politikáját és az egyezménnyel kapcsolatos nemzeti vállalásaik teljesitését (Druzin, 2016). Hiszen a kilépéssel együitt járó, a termelést szabályozó, esetenként kevésbé szigorú jogi környezet egyúttal nagyobb haszonszerzési lehetőségeket is kínál. Ilyen értelemben a kilépő államok olyan előnyre tehet nek szert, amely - egy, az államok önérdekkövetésére és a nemzetközi rendszert jellemző versenyhelyzetre való tekintettel - könnyen más államokat is a kilépésre ösztönözhet.

22 Az éghajlatváltozás kapcsán kialakult nemzetközi fellépés esetében ez az ún. fragmentált vezetési forma (fragmented leadership landscape) (Parker és Karlsson. 2018, 530. о.) 


\section{Külïgyi Szemle}

szerződéshez füzött kiegészítés vagy a kombinált reakciók lehetősé geirôl is elgondolkodott (Kemp, 2016). Annyi bizonyos, hogy a kivonu lás - a nemzetközi monitoring tevékenység elkerülése, a szerződésből és az egyoldalú kötelezettségvállalásokból fakadó (ha nem is jogi, de morális) elszámoltathatóság kiküszöbölése és a fejlődỏ államoknak nyújtandó financiális hozzájárulás megszüintetése révén - a válasz tóknak tett trumpi ígérettel összhangban a szuverenitás megőrzésé nek a látszatát kelthette. Azonban úgy gondolom, ez a gyakorlatban nem jelentett kötetlenebb, szabadabb döntéshozatalt - és bármely részes állam hasonló döntése a jövőben sem fog azt jelenteni -, hiszen az egyezmény bemutatott rugalmasságából fakadóan a verifikációs és szankciós politika hiánya a szerződéses keretek között is lehetővé tette volna az amerikai pálfordulást, illetve a belpolitikai jogi környezet átalakítását. E forgatókönyv pedig talán kevésbé okozta volna az ország nemzetközi megítélésének a romlását és bizonyos államokkal (például Kínával) az egyébként is gondterhelt diplomáciai kapcsolatai erodálódását.

Az egyezménynek a 2020 novemberében érvénybe lépett elha gyását követően már gondolni lehetett az amerikai-kínai kapcsola tok esetleges drasztikus megromlására, de olyan is akadt, aki például a világ harmadik legnagyobb szennyezőanyag-kibocsátó országaként számon tartott India kötelezettségvállalásainak az elhalasztásától, fellazulásától tartott (Davenport és Rubin, 2017). Az azonban bizo nyos, hogy a kivonulással kapcsolatos döntés nem lehetett meglepetésszerű, hiszen Donald Trump lineáris klímapolitikája a 2017-es beiktatástól kezdve konzekvensen integrálta az obamai klímapolitika lépcsőzetes leépítését, s ebben még az európai - széles értelemben vett - jobboldal támogatását is sok tekintetben élvezte (lásd például: Logan, 2017). A republikánus kormányzat által használt, a nemzeti szuverenitás „visszaszerzésére” és az amerikai gazdaság védelmére irányuló impulzív retorikai fogások ellenére úgy tủnik, hogy a gyakor latban a Trump-adminisztráció alatt a szénkitermelési adatok válto zatlanok maradtak, sőt több mint 3 százalékkal le is csökkentek (U.S. Energy Information Administration, é. n.), a szén-dioxid-kibocsátás 
pedig „csupán” kismértékben növekedett. Ezek fényében tehát alapjaiban megkérdőjelezhető a nemzetközi együttmúködésből való kihátrálás szükségszerűsége.

Az éghajlatváltozás kérdéskörének az előtérbe kerülése és a pári zsi egyezményből való kilépés nyilvánvalóan meghatározó pontja lett a 2020-as amerikai elnökválasztásnak is. A párizsi egyezmény célkitűzéseivel összhangban álló ún. Green New Deal Joe Biden elnökké választása óta új, potenciális lehetőségként szerepel az amerikai klímapolitika terén (Bruggers, 2020; Ayesh, 2020), és az Obama-féle politika továbbvitelét, a párizsi célok iránti elköteleződés megerősítését (Downie, 2020) is magában foglalja. Ez különösen nagy relevanciával bír Biden elnöki ciklusának az elején, hiszen a jelenlegi Covidl9 járvány kapesán az éghajlatváltozással szembeni aktív politikát és fellépést sürgető csoportok mind az Európai Unióban (Todorović, 2020a; Todorović, 2020b; Simon, 2020), mind az Egyesült Államok ban (Lashof, 2020) progressziv, környezettudatos szemléletet tükröző javaslatokkal kívánnak nyomást gyakorolni a döntéshozókra, hogy azok a vírus okozta gazdasági visszaesést követő helyreállítás során a fenntarthatóság és a környezetvédelem szem előtt tartásával hozzák meg a szüikséges döntéseket.

Az idén január 20-án beiktatott Joe Biden ezért azonnal nyilvánvalóvá tette a párizsi egyezmény iránti elköteleződését, tettrekészségét, valamint az újracsatlakozásra való határozott igényét (The White House, 2021). Az egyezményben előírt, a kilépést követő 30 nap leteltével a demokrata elnök jogszerűen dönthetett az újracsatlakozás megkezdé séról, s utasíthatta az illetékes szövetségi szerveket az újracsatlakozási folyamat megindítására (Davenport és Friedman, 2021), melynek eredményeképpen az Egyesült Államok ismét annak részesévé vált. Mindemellett az elnök április 22-23-ára egy nemzetközi csúcstalálkozót is kilátásba helyezett. A konferencián, amelynek célja - amerikai részről - a károsanyag-kibocsátás terén meghatározott amerikai célok teljesítésének a garantálása, valamint új vállalások megfogalmazása volt (Milman, 2021), a világ tizenhét legnagyobb gazdasága és károsanyagkibocsátó országa mellett az éghajlatváltozásnak leginkább kitett államok is képviseltették magukat (U.S. Deparlment of Sıate, é. n.). 


\section{Külïgyi Szemle}

\section{Diszkusszió}

Az 1970-es évek óta zajló nemzetközi környezetvédelmi diskurzus az Egyesült Államokban eleinte kétpárti támogatással zajlott, majd po larizált környezetben folyt tovább, amelynek során kialakult egy bizo nyos demokrata „zöldpártiság” és egy, a gazdasági növekedést és az üzleti érdekeket prioritásként kezelő republikánus kettősség (Henry, 2017). Az utóbbi évtizedek során a demokrata elnökök a környezetvédelemmel és az éghajlatváltozással kapcsolatban együittműködésre törekedtek, míg a republikánusok elutasító és protekcionista politikát képviseltek. A párizsi egyezményből való republikánus kihátrálás is ebbe a trendbe illeszkedett, de nem jelentette az Egyesült Államoknak a nemzetközi összefogásból való végleges kivonulását. Trump re torikája pusztán egy republikánus - a saját szemszögéból realistának tűnő elveket követő, e téren a protekcionista szemléletbe illeszkedő, valamiféle rövid távú költséghaszon-elemzésen alapuló, az egyezményt az amerikai gazdasági érdekekkel ellentétesnek tartó, a hazai gazdasági érdekeket kiszolgáló - és a korábbi elnöki tevékenységgel szembehelyezkedô politikát sejtetett. Ez, tekintettel az elnök üzleti múltjára, bizonyos mértékig érthető is volt. Mindennek ellenére az elmúlt évek során nagyjából egyértelmúvé vált - elég, ha csak az első fejezetben említett, a tengerszint emelkedésével és az alacsonyan fekvő államok helyzetével kapcsolatos problémakörre is gondolunk -, hogy az éghajlatváltozás mára a nemzetközi kapcsolatokat meghatározó terüilet lett.

A párizsi egyezményből való amerikai kihátrálás arra is rávilágít hat, hogy a környezetvédelmi szabályozásnak az adott államok ve zetői helyett az állam alatti szereplők irányába történő eltolódása szükségszerűen a hatékonyabb fellépést és a téma átpolitizáltságá nak a csökkenését, a nemzetközi közösség ,zöldesítését” jelentheti (Falkner, 2012, idézi Henry, 2017). Az NGO-knak (non-governmental organisations) az éghajlatváltozással kapcsolatos nemzetközi diskur zusban és a vonatkozó tárgyalások során betöltött szerepének a növe kedése már az 1990-es években megfigyelhető volt, s már akkor is volt, 
aki a nem állami szektor felértékelődését prognosztizálta (Giorgetti, 1998). Ugyanakkor érdemes felhívni a figyelmet arra, hogy az állam alatti, illetve a nem állami aktorok jelentőségének a növekedése, amely korunkban egyre inkább jellemző, nem szükségszerủen jelenti az államközpontú szemlélet teljes körű mellôzését. ${ }^{23}$

A nem állami aktorok felé fordulás, illetve a szövetségi rendszerú országok esetében az egyes államok irányába való elmozdulás ${ }^{24}$ tehát az amúgy is jellemző komplexitást, többoldalú összekapcsolódást erősítheti a környezetvédelmi regulációban érdekelt szereplők között.

\section{Összegzés}

Míg sokan a párizsi egyezmény korszakhatárként értelmezett sikeréről, esetleg a lehetőségekhez képest pozitív eredményeirôl érte keznek, addig az egyezmény szövege és tartalma, valamint a fejlett államok érdekérvényesítése mentén kialakult államközi kompromisszumok inkább az utóbbiak sikerét támasztják alá, és az amerikai érdekek minden kulcskérdésben érvényesüiltek. Az amerikai kor mánynak a kötelezettségvállalások teljesítése iránti együttmúködési hajlandósága Donald Trump elnökké választásával, azaz 2017-től folyamatosan csökkent. Az új republikánus elnök - a kampányígéretéhez híven - az egyezmény szövegében is megnyilvánuló amerikai sikerek ellenére 2019-ben hivatalosan is arról értesítette az Egyesült Nemzetek Szervezetének a főtitkárát, hogy kivonja hazáját az egyezményből. Az éghajlatváltozással szembeni fellépés kapcsán kialakult republikánus izolacionizmus és destruktív megközelítés az amerikai gazdasá gi, ipari érdekek elsőbbségének, a nemzeti szuverenitás visszaszer zésének igényével és konzekvens politikai döntések révén vezetett el

23 Például egy, az éghajlatváltozás következményeit Nigéria - azon belül pedig a klíma változásnak leginkább kitett területei - kontextusában vizsgáló kérdốives felmérés a nem állanini szereplők jelentősége mellett az infrastrukturális tényezők kapcsán az állam kiemelt szerepére hívja fel a figyelmet (Azubuike és Opara, 2016).

24 Például éppen a Trump-féle kihátrálást követően erősödött meg az Egyesült Államokban a párizsi vállalások teljesítése iránt elkötelezett államok közötti összefogás az akkor megalapított United States Climate Alliance keretein belül. 


\section{Külïgyi Szemle}

2020 -ra az Egyesült Államok kilépéséhez. A kihátrálás azonban nem jelentette az Egyesült Államoknak az éghajlatváltozás elleni küzdelem terén való elköteleződésének a végérvényes megszűnését. Joe Biden elnök a korábbi demokrata klímapolitika továbbvitelével és a párizsi egyezményhez való újracsatlakozással az elmúlt négy évhez képest egy határozottan új irányba terelheti az amerikai klímapolitikát.

\section{I rodalom.jegyzék}

Ang, Wilson (2016). What's Next for Singapore After Paris Agreement? ECO Singapore. A letöltés ideje: 2020. május 9. https://www.academia. edu/19940297/Whats next for_Singapore after_Paris Agreement.

Arcanjo, Marcus (2019). Has Climate Change Renderedt he Concept of Sovereignty Obsolete? Climale Instilute. A letöltés ideje: 2020. június 15. https://climate.org/has-climate-change-rendered-the-concept-ofsovereignty-obsolete/.

Ayesh, Rashaan (2020). Where Top 2020 Candidates Stand on Climate Policy and the Green New Deal. Axios. A letöltés ideje: 2020. június 16. https://www.axios.com/2020-presidential-candidates-green-newdeal-22faff60-3fee-45f3-8636-09e437c82431.html.

Azubuike, Ozioma C. és Opara, Jacinta A. (2016). Impact of Climate Change on the Role of Non-Governmental Organizations in Environmental Health Delivery in South-Eastern Region of Nigeria. Scientific Journal "ScienceRise", 4(1) (21). A letöltés ideje: 2021. április 12. https://doi. org/10.15587/2313-8416.2016.67435.

Bodansky, Daniel (2016). The Legal Character of the Paris Agreement. Review of European Communily \& International Environmental Lav, 25(2). A letöltés ideje: 2021. április 12. https://jak.ppke.hu/uploads/ articles/1211121/file/Bodansky-2016-RECIEL\%20Paris\%20Legal\%20 Character.pdf.

Brewer, Contessa és Golden, Jessica (2016). In This Swing State, Coal Country Is Trump Country. CNBC. A letöltés ideje: 2021. április 12. https://www.cnbc.com/2016/10/12/in-this-swing-state-coal-countryis-trump-countrv.html.

Bruggers, James (2020). Joe Biden on Climate Change: Where the Candidate Stands. Inside Climate News. A letöltés ideje: 2021. április 12. https:/insideclimatenews.org/news/24062019/joe-biden-climatechange-global-warming-election-2020-candidate-profile. 
Chin-Yee, Simon (2016). Briefing: Africa and the Paris Climate Change Agreement. African Affairs, 1-10.

Climate Action Tracker (é. n.). Climate Action Tracker. A letöltés ideje: 2020. június 18. https://climateactiontracker.org/.

Congress.gov (1997). S. Res.98 - A Resolution Expressing the Sense of the Senate Regarding the Conditions for the United States Becoming a Signatory to Any International Agreement on Greenhouse Gas Emissions Under the United Nations Framework Convention on Climate Change. A letöltés ideje: 2021. április 10. https://www.congress. gov/bill/105th-congress/senate-resolution/98.

Davenport, Coral (2015). Nations Approve Landmark Climate Accord in Paris. The New York Times. A letöltés ideje: 2020. május 11. https://www. nytimes.com/2015/12/13/world/europe/climate-change-accord-paris. html? $\mathrm{r}=0$.

Davenport, Coral és Friedman, Lisa (2021). Biden Cancels Keystone XL Pipeline and Rejoins Paris Climate Agreement. The New York Times. A letöltés ideje: 2021. február 10. https://www.nytimes.com/2021/01/20/ climate/biden-paris-climate-agreement.html.

Davenport, Coral és Rubin, Alissa J. (2017). Trump Signs Executive Order Unwinding Obama Climate Policies. The Nem York Times. A letöltés ideje: 2020. május 12. https:/www.nvtimes.com/2017/03/28/climate/ trump-executive-order-climate-change.html? $r=0 . \% 20$ Last $\% 20$ accessed $\% 2027$ th $\% 20$ Mar\%202017\&auth-login-email\&login=email.

Dimitrov, Radoslav S. (2016). The Paris Agreement on Climate Change: Behind Closed Doors. Global Environmental Politics, 16(3), 1-11. A letöltés ideje: 2021. április 12. https://doi.org/10.1162/GLEP_a_00361.

Downie, Christian (2020). Biden Says the US will Rejoin the Paris Climate Agreement in 77 Days. Then Australia will Really Feel the Heat. The Conversation. A letöltés ideje: 2020 . november 11. https://theconversation. com/biden-savs-the-us-will-rejoin-the-paris-climate-agreement-in77-davs-then-australia-will-really-feel-the-heat-149533.

Druzin, Bryan H. (2016). A Plan to Strengthen the Paris Agreement. Fordham Law School. Res Gasıae, 18. A letöltés ideje: 2021. április 12. https:// ir.lawnet.fordham.edu/cgi/viewcontent.cgi?referer=https://www.google. $\mathrm{com} /$ \&httpsredir $=1$ \&article $=1025$ \&context $=$ res gestae.

Eckersley, Robyn (2007). Ecological Intervention: Prospects and Limits. Ethics and International Affairs, 21(3), 293-316. 


\section{Külüigyi Szemle}

U.S. Energy Information Administration (é. n.). Coal Overview. A letöltés ideje: 2021. április 12. https://www.eia.gov/totalenergy/data/monthly/ $\mathrm{pdf} / \mathrm{sec} 6$ 3.pdf.

Falk, Richard (2016). 'Voluntary' International Law and the Paris Agreement. Global Justice in the 21s/ Century. A letöltés ideje: 2020. május 12. https:// richardfalk.wordpress.com/2016/01/16/voluntary-international-lawand-the-paris-agreement/.

Falkner, Robert (2012). Global Environmentalism and the Greening of International Society. International Affairs, 88(3), 503-522.

Fearnside, Philip (2019). Commentary: Will President Bolsonaro withdraw Brazil from the Paris Agreement? MONGABAY. A letöltés ideje: 2020. május 9. https://news.mongabav.com/2019/01/commentarv-willpresident-bolsonaro-withdraw-brazil-from-the-paris-agreement/.

Gilpin, Robert és Gilpin, Jean M.(2001). Global Political Economy: Understanding the International Economic Order. Princeton, NJ: Princeton University Press.

Giorgetti, Chiara (1998). The Role of Nongovernmental Organizations in the Climate Change Negolialions. Richmond, VA: University of Richmond UR Scholarship Repository Law Faculty Publications.

Global Carbon Allas (2019). A letöltés ideje: 2021. április 10. http://www. globalcarbonatlas.org/en/CO2-emissions.

Goldenberg, Suzanne (2015a). Barack Obama: Parts of Paris Climate Deal Must Carry Legal Force. The Guardian. A letöltés ideje: 2020. május 12. https://www.theguardian.com/environment/2015/dec/01/barackobama-parts-of-paris-climate-deal-must-carrv-legal-force.

Goldenberg, Suzanne (2015b). How US Negotiators Ensured Landmark Paris Climate Deal Was Republican-Proof. The Guardian. A letöltés ideje: 2020. május 12. https://www.theguardian.com/us-news/2015/dec/13/ climate-change-paris-deal-cop21-obama-administration-congressrepublicans-environment.

Goldenberg, Suzanne és Roberts, Dan (2015). Obama Rejects Keystone XL Pipeline and Hails US as Leader on Climate Change. The Guardian. A letöltés ideje: 2020. május 12. https://www.theguardian.com/ environment/2015/nov/06/obamarejects-kevstone-xl-pipeline.

Green, Miranda (2019). Trump Admin Submits Final Rule to Kill Obama Clean Power Plan. The Hill. A letöltés ideje: 2020. május 12. https:// thehill.com/policy/energy-environment/449303-trump-adminsubmits-final-rule-to-kill-obama-clean-power-plan. 
H. F. Li, Anthony (2016). Hopes of Limiting Global Warming? China and the Paris Agreement on Climate Change. China Perspectives, 1, 49 54. A letöltés ideje: 2020. május 9. http://journals.openedition.org/ chinaperspectives/6924.

Habib, Benjamin (2015). Climate Change and the Re-imagination of State Sovereignty. E-International Relations. A letöltés ideje: 2021. április 12. https://www.e-ir.info/2015/11/08/climate-change-and-the-reimagination-of-state-sovereignty.

Halper, Evan és Zavis, Alexandra (2017). Trump Quits the Paris Climate Accord, Denouncing It as a Violation of U.S. Sovereignty. Los Angeles Times. A letöltés ideje: 2020. júnuis 15. https://www.latimes.com/ politics/la-na-pol-trump-paris-20170601-storv.html.

Harvey, Fiona (2015). World's Climate Pledges Not Yet Enough to Avoid Dangerous Warming - UN. The Guardian. A letöltés ideje: 2020. május 11. https://www.theguardian.com/environment/2015/oct/30/worldsclimate-pledges-likely-to-lead-to-less-than-3c-of-warming-un.

Henry, Matthew L. (2017). U.S. Environmental Policy and the Paris Agreement. Norwich Universily, IR 520 Term Paper. A letöltés ideje: 2021. április 12. https:/www.academia.edu/38557506/U.S. Environmental Policy and the Paris Agreement.

Johnson, Keith (2019). Is the United States Really Leaving the Paris Climate Agreement? Foreign Policy. A letöltés ideje: 2020. június 18. https:// foreignpolicv.com $/ 2019 / 11 / 05 /$ paris-climate-agreement-united-stateswithdraw/.

Johnston, Ian (2017a). Clexit: Former Oil Boss May Be Only Hope of Stopping Donald Trump from Ditching Paris Climate Change Agreement. Independent. A letöltés ideje: 2020. május 13. https://www.independent. co.uk/news/world/americas/us-politics/clexit-donald-trump-ditchparis-climate-change-agreement-oil-boss-secretary-of-state-rextillerson-a7609051.html.

Johnston, Ian (2017b). Exxon Mobil Urges Donald Trump to Keep US Signed up to Paris Agreement on Climate Change. Independent, A letöltés ideje: 2020. május 12. https://www.independent.co.uk/news/world/americas/ us-politics/exxon-mobil-donald-trump-paris-agreement-climatechange-us-signatory-global-warming-rex-tillerson-a7655391.html.

Kemp, Luke (2016). US-Proofing the Paris Climate Agreement. Climate Policy, 17(1), 86-101. A letöltés ideje: 2021. április 12. http://dx.doi.org/10. $\underline{1080 / 14693062.2016 .1176007 .}$. 


\section{Külïgyi Szemle}

Lashof, Dan (2020). US Coronavirus Response: 3 Principles for Sustainable Economic Stimulus. World Resource Instilute. A letöltés ideje: 2020. június 16. https://www.wri.org/blog/2020/03/coronavirus-USeconomic-stimulus.

Logan, Ross (2017). 'Dear Donald' - MEPs Pen 'love letter' to President Trump to Scrap Climate Change Policy. Express. A letöltés ideje: 2020. május 13. https:/www.express.co.uk/news/world/789177/MEPs-loveletter-Donald-Trump-scrap-Paris-agreement-climate-change.

Lomborg, Bjorn (2015). A Climate Agreement Powered by Hypocrisy. Project Syndicate. A letöltés ideje: 2020. május 11. www.project-svndicate.org/ commentary/paris-climate-agreement-hypocrisy-by-bj-rn-lomborg.

Marton Péter és Hoffmann Tamás (2020). The Responsibility to Protect Principle and State Negligence in Disease Prevention of International Concern. TKJTI. A letöltés ideje: 2020. június 15. https://jog.tk.mta.hu/ blog/2020/05/the-responsibility-to-protect-hu.

Mathiesen, Karl és Harvey, Fiona (2015). Climate Coalition Breaks Cover in Paris to Push for Binding and Ambitious Deal. The Guardian. A letöltés ideje: 2020. május 12. https://www.theguardian.com/environment/2015/ dec/08/coalition-paris-push-for-binding-ambitious-climate-change-deal.

Milman, Oliver (2016). Obama's Climate Change Legacy at Stake as Clean Power Plan Has Its Day in Court. The Guardian. A letöltés ideje: 2020. május 13. https://www.theguardian.com/environment/2016/sep/28/ clean-power-plan-court-obama-climate-change.

Milman, Oliver (2017). Trump Begins Rollback of Obama's Car Pollution Standards to Curb Emissions. The Guardian. A letöltés ideje: 2020. május 13. https:/www.theguardian.com/us-news/2017/mar/15/carpollution-carbon-emissions-obama-trump-epa.

Milman, Oliver (2021). Biden Returns US to Paris Climate Accord Hours After Becoming President. The Guardian. A letöltés ideje: 2021. február 10. https://www.theguardian.com/environment/2021/jan/20/parisclimate-accord-joe-biden-returns-us.

Monbiot, George (2009). If yYou Want to Know Who's to Blame for Copenhagen, Look to the US Senate. The Guardian. A letöltés ideje: 2020. május 12. https://www.theguardian.com/commentisfree/2009/ dec/21/copenhagen-failure-us-senate-vested-interests.

Natural Resources Defense Council (2017). What Is the Clean Power Plan? A letöltés ideje: 2021. március 14. https://www.nrdc.org/stories/howclean-power-plan-works-and-why-it-matters. 
Oil Change Internatonal (é. n.). Oil Change International. A letöltés ideje: 2020. május 13. http://priceofoil.org/fossil-fuel-industry-influence-in-the-u-s/.

Ourbak, Timothée és Magnan, Alexndre K. (2017). The Paris Agreement and Climate Change Negotiations: Small Islands, Big Players. Regional Environmental Change, 18(1). A letöltés ideje: 2021. április 12. https://doi. org/10.1007/s10113-017-1247-9.

Parker, Charles F. és Karlsson, Christer (2018). The UN Climate Change Negotiations and the Role of the United States: Assessing American Leadership from Copenhagen to Paris. Environmental Politics, 27(3), 519-540. A letöltés ideje: 2021. április 12. https://doi.org/10.1080/0964 4016.2018.1442388.

Pengelly, Martin (2017). Trump to Sign Executive Order Undoing Obama's Clean Power Plan. The Guardian. A letöltés ideje: 2020. május 12. https:// www.theguardian.com/environment $/ 2017 / \mathrm{mar} / 26 / \mathrm{trump}$-executiveorder-clean-power-plan-coal-plants.

Rajamani, Lavanya (2016). Ambition and Differentiation in the 2015 Paris Agreement: Interpretative Possibilities and Underlying Politics. International and Comparative Law Quarterly, 65(2), 493-514. A letöltés ideje: 2021. április 12. https://www.cambridge.org/core/journals/ international-and-comparative-law-quarterly/article/ambitionand-differentiation-in-the-2015-paris-agreement-interpretativepossibilities-and-underlying-politics/CD4237FABBA8B88854F093 BC02453960/core-reader.

Rayfuse, Rosemary és Crawford, Emily (2011). Climate Change, Sovereignty and Statehood. In Rosemary Rayfuse és Shirley V. Scott (szerk.), International Law in the Era of Climate Change. https://papers.ssrn. com/sol3/papers.cfm?abstract id=1931466.

Reuters (2017). German Carmakers Fear Losing Competitive Edge After U.S. Paris Exit. A letöltés ideje: 2020. május 13. https://www.reuters.com/ article/us-usa-climatechange-german-carmakers-idUSKBN18T1QO.

Russonello, Giovanni (2015). Two-Thirds of Americans Want U.S. to Join Climate Change Pact. The New York Times. A letöltés ideje: 2020. május 12. https:/www.nytimes.com/2015/12/01/world/americas/us-climatechange-republicans-democrats.html? $\mathrm{r}=2$.

Simon, Frédéric (2020). 'Green Recovery Alliance' Launched in European Parliament. Euraclive. A letöltés ideje: 2021. április 12. https:/www. euractiv.com/section/energy-environment/news/green-recoveryalliance-launched-in-european-parliament. 


\section{Külïgyi Szemle}

Sina (2015). China-U.S. Climate Leadership Declaration Clarifies the Action Plan for Carbon Emission Reduction of the Two Countries (angol fordítás). A letöltés ideje: 2020. május 11. http://inance.sina.com.cn/ world $/ 20150924 / 021923333519$. shtml.

Taddonio, Patrice (2019). Bob Murray Helped Shape Trump's Energy Policies. Now, His Coal Company Is Facing Bankruptcy. PBS Fronlline. A letöltés ideje: 2021. április 27. https://www.pbs.org/wgbh/frontline/ article/bob-murray-helped-shape-trumps-energy-policies-now-hiscoal-company-is-facing-bankruptev.

The Washington Post (é. n.). Should We Rejoin the Paris Agreement? A letöltés ideje: 2020. június 18. https://www.washingtonpost.com/ graphics/politics/policy-2020/climate-change/rejoining-paris-climateagreement/.

The While House (2021) Paris Climate Agreement. A letöltés ideje: 2021. január 20. https://www.whitehouse.gov/briefing-room/statementsreleases/2021/01/20/paris-climate-agreement/.

The While House, Office of the Press Secrelary (2014). U.S.-China Joint Announcement on Climate Change. A letöltés ideje: 2021. április 12. https://obamawhitehouse.archives.gov/the-press-office/2014/11/11/uschina-joint-announcement-climate-change.

The While House, Office of the Press Secrelary (2015a). Remarks by President Obama at the First Session of COP21. A letöltés ideje: 2021. április 12. https://obamawhitehouse.archives.gov/the-press-office/2015/11/30/ remarks-president-obama-first-session-cop21.

The While House, Office of the Press Secrelary (2015b). U.S.-China Joint Presidential Statement on Climate Change. A letöltés ideje: 2021. április 12. https://obamawhitehouse.archives.gov/the-press-office/2015/09/25/ us-china-joint-presidential-statement-climate-change.

Todorović, Igor (2020a). EU Heads Promise to Stick with Sustainability in COVID-19 Recovery. Balkan Green Energy News. A letöltés ideje: 2020. június 16. https://balkangreenenergynews.com/eu-heads-promise-tostick-with-sustainability-in-covid-19-recovery.

Todorović, Igor (2020b). Officials, CEOs, NGOs Call for Green Revival from COVID-19 in EU. Balkan Green Energy News. A letöltés ideje: 2020. május 16. https://balkangreenenergynews.com/officials-ceos-ngos-callfor-green-revival-from-covid-19-in-eu/.

U.S. Department of State, Office of the Spokesperson (2017). Communication Regarding Intent to Withdraw from Paris Agreement. A letöltés 
ideje: 2017. augusztus 4. https://2017-2021.state.gov/communicationregarding-intent-to-withdraw-from-paris-agreement/index.html.

United Nations (2015). Paris Agreement. A letöltés ideje: 2021. április 12. https://unfecc.int/files/essential_background/convention/application/ pdf/english_paris_agreement.pdf.

Uniled Nations Treaty Collection (é. n.). Status of Treaties. A letöltés ideje: 2021. április 12. https://reaties.un.org/Pages/ViewDetails. aspx?src=TREATY\&mtdsg no $=$ XXVII-7-d\&chapter $=27 \&$ clang $=$ en.

We Are Still In (é. n.). America Is All In. A letöltés ideje: 2020. június 18. https://www.wearestillin.com/.

Werrell, Caitlin E. és Femia, Francesco (2016). Cimate Change, the Erosion of State Sovereignty, and World Order. Brown Journal of World Affair, 22(2). A letöltés ideje: 2021. április 12. https://climateandsecuritv.files. wordpress.com $/ 2012 / 04 /$ werrell_femia_final-article_climate-changestate-sovereignty world-order.pdf. 